\title{
INTRA-SENTENTIAL SWITCHING USE IN CLASSROOM ACTIVITY
}

\author{
Muji Adi Mujiono1, Thalia Medina Diputri ${ }^{2}$ \\ ${ }^{1}$ IKIP Siliwangi \\ ${ }^{2}$ IKIP Siliwangi \\ ${ }^{1}$ dimujionoo@gmail.com, ${ }^{2}$ thaliamedina646@gmail.com
}

\begin{abstract}
The research focused in the intra-sentential code switching used by the students in English Department of IKIP Siliwangi Bandung. The research was conducted to find out the intra-sentential switching that used by the students, why the students switch code, and the function of intra-sentential switching in classroom activity. The research employed a qualitative descriptive study involing field research. The samples are 3 groups presentation from class A2 English Education 2015 IKIP Siliwangi Bandung. This study explored pattern of intra-sentential code-switching (CS) that are manifest in classroom activity of English-Indonesia-Sunda in class A2 English Education 2015 IKIP Siliwangi Bandung, the reason why students switch thier code and in what situation students switch their code or language. The result of this research are 3 groups presentation were switching their language in type of intra-sentential switching, the reasons they switch their langugae are less vocabulary, to make they easier to express their mind, to make listener or audience easier to understand, and nervous. In presentation, group discussion, speech \& daily conversation are situations they switch their code or language.
\end{abstract}

Keywords: Code switching, Intra-sentential switching, classroom activity.

\section{INTRODUCTION}

Language is a tool that people use to communicate with each other. Most of Indonesian are able to speak more than one language in their daily live. Indonesian students learn some subject in learning language, there are Indonesia language, English language, Sundanese language, Japan language, etc. English is a foreign language in Indonesia. In some school and university in Indonesia use English in teaching and learning activity in classroom. Not only to transfer the knowledge from teacher / lecturer to students but also to present and transfer information and knowledge from students to students. Sometimes teachers/ lecturers and students in EFL classroom switch the language from English to Indonesia. This is called as code switching. According to (Romaine, 1992) in (Nur, 2016) "Code-switching can be defined as the use of more than one language, variety, or style by a speaker within an utterance or discourse, or between different interlocutors or situations". Code-switching is one of linguistic phenomenon that occurs in bilingual or multiligual speech communities. The case of switching from one language to another language is accepted as a quite normal phenomenon in Indonesia.

This research analyzed the way students switching code their languge in classroom activity (presentation), because in the classroom students use 3 language, there are English language, Indonesia language, and Sundaness language. It is possible for them to switching code. The reasons why students switch their code or language. And in what situation students switch their code or language. 
The Aims of the research was to find out the intra-sentential switching that used in classroom activity (presentation), the reasons why students switch thier code or language, and in what situation students switch their code or language.

According to (Li, 2008) "Code-switching (CS) refer to the alternate use two or more languages in an extended stretch of discourse, where the switch takes place at sentence or clause boundaries". (R Wardhaugh, 2006) said that "People, then, are usually required to select a particular code whenever they choose to speak, and they may also decide to switch from one code to another or to mix codes even within sometimes very short utterances and thereby create a new code in a process known as code-switching".

Code-switching can be defined as the use of more than one language, variety, or style by a speaker within an utterance or discourse, or between different interlocutors or situations (Romaine, 1992) in (Nur, 2016). Code switching occurs mostly in bilingual communities. Speakers of more than one language are known for their ability to code switching or mix their language during their communication. As (Aranoff, Rees, \& Miller, 2003) indicate, many linguists have stressed the point that switching between languages is a communicative potion available to a bilingual member of a speech community, on much the same basis as switching between styles or dialects is an option for the monilingual speaker.

According to (D, 1987) in (Kaswan \& Suprijadi, 2011) there are some reasons why speakers use code-switching.

The first of these is the notion that speaker who may not be able to express him/herself in one language switches to the other to compensate for deficiency. Secondly, switching commonly occurs when an individual wishes to express solidarity with a particular social group. Third, the switch between language can signal the speaker's attitude to the listenerfriendly, irritated, distant, and so on.

(Appel., R., \& Muysken, 1987) in (Yuliana, Luziana, \& Sarwendah, 2015), et.al (2015 : 48) stated that intrasentential code-switching is the alternation in a single discourse between two languages, where the switching occurs within a sentence. (Hughes, B., Baldwin, T., Bird, S., Nicholson, J., \& MacKinlay, 2006) in (Yuliana et al., 2015), et.al. (2015:48) also stated that intersentential is inserting an entire phrase from the secondary language into a conversation using the other language.

\section{METHOD}

This research is qualitative that employs descriptive method. by doing observation and interview. There were several steps in analyzing the data. First, we record 3 groups prensentation in class A2 English Education 2015 at IKIP Siliwangi Bandung. Second, we analyzed what the students said in video and what the intra-sentential code-switching they used. Third, we interviewed the stundents that were switching their language in the video.

\section{RESULT AND DISSCUSION}

Code-Switching and Code-Mixing in EFL teaching at IKIP Siliwangi Bandung. The data in this study are derived from observation checklist. The observation sessions have been conducted in one semester in academic year 2015 in undergraduate program of English Education at IKIP Siliwangi Bandung.

\section{Research Finding}




\section{A. Result of observation:}

- Group 1

1) They still ragu-ragu.

- $\quad$ Group 2

1) Jadi student menyadari.

2) Karena mereka memakai $\underline{G E}$, kebutuhan mereka tidak tepenuhi.

3) Jadi kami memberikan questionnaire kepada beberapa siswa.

4) Semua skill itu penting tapi tidak sesuai dengan jurusan.

5) Di dalam kelas mereka lebih banyak practice.

6) Karena gurunya juga kurang menggunakan speaking.

7) Mereka menjawab tapi sometimes.

8) Di sekolah mereka menggunaan GE, General English.

9) Jadi mereka kurang mengikuti pronunciation nya belum bagus karena $\underline{G E}$.

10) Grammar, tenses, vocabulary terlalu cepat dalam pembahasannya.

- $\quad$ Group 3

1) Lesson plan from MGMP atau Musyawarah Guru Mata Pelajaran.

2) Learning material for first grade of TP use modul because there is dana from Pemerintah.

3) Ini contoh assessment rubric yang diambil dari RPP yang diambil dari miss Vivi.

4) Meskipun $G E$ tapi pas kita observasi ke anak-anaknya mereka membutuhkan ESP.

Based on the data above, we found that 3 groups that were doing presentation use intrasentential code switching. The language that they switched were Indonesia language and English language. As we can see the group 1 switched their language once and the group 2 switched their language ten-times. The group 1 more used English language, group 2 more used Indonesia language, and group 3 used Indonesia and English language in a balanced way.

\section{Result of Interview}

Based on the interview that already did, the researchers asked four questions to group 1, group 2, and group 3.

For the questions numbers 1 about why you switching your code or language?, the result from group 1 is less vocabulary, nervous make us forget words that want to said in target language, and to make easier to express words in our mind, from group 2 is To make listeners more easier to understand about what have been said, Less vocabulary, and To make us easier to express what in our mind . and the result from group 3 is To make the listener or audience more understand, and because they nervous.

The questions number 2 about what language that you usually use?, the result from group 1 is Indonesian, Sunda, and English language. From group 2 is Indonesia, Sunda, Java, English. And from group 3 is Indonesia.

The questions number 3 is about what language that you usually switch?, the result from group 1 is Indonesia switch with English, and vice versa, Sunda switch with Indonesia, and vice versa. From group 2 is English switch with Indonesia language and vice versa, Sunda switch with Indonesia language and vice versa, Java switch with Indonesia language and vice versa, and the result from group 3 is English switch with Indonesia language and vice versa, Sunda switch with Indonesia language and vice versa.

The last questions is about in what situation you switch your code or language?, from the result group 1 is presentation and forum group, from group 2 is Presentation, speech, discussion, and daily coversation. And the resut from group 3 is Presentation, daily conversation. 
Based on result above, we can see that most reason why students switch their code are because less vocabulary and to make their easier to express what in their mind. The language that most usually use are Indonesia, English, and Sunda. Group1, group 2, and group 3 are usually switch all the language that they usually use in daily life. In presentation and discussion are the most situations that they switching their code or language.

\section{Discussion}

As the researcher wrote at introduction, this research purposed to find out the intra-sentential switching that used in classroom activity (presentation), the reason why students switch thier code and in what situation students switch their code or language.

\section{Intra-sentential Switching}

Based on the observation that have been taken. The writer calculated words that include to intrasentential switching from the participant that consist 2 groups. The result is there are 15 sentences of intra-sentential switching. Group 1 was switching their code once, group 2 was switching their code 10 times, and group 3 was switching their code 4 times. The languages that group 1, group 2, and group 3 switch are English and Indonesia language. In group 1, they more used English language than Indonesia language. Group 2 more used Indonesia language than English language. And in group 3 they balanced in using their language between Indonesia and English.

\section{The Reason of Switch Code or Language}

Based on the interview that have been taken. The writer got the reasons why students switch their language. The first, it is because the students have less vocabulary. Second, because switching code can make them easier to express or tell their ideas or words to the listener. Third, to make the listener more understand of what they said. Fourth, because feel nervous make students forget about the words or ideas that they want to say in target language.

\section{The Situation of Switch Code or Language}

Based on the interview that have been taken. The writer got in what situation students switch their code or language. First, they usually switch their code or language when they doing presentation in the class. Second in daily conversation, they switch their code or language when they do conversation with their friends, family, or with their lecturer. Third, they switch their code or language when they doing speech. Fourth in discussion or group discussion they usually switch their code or language.

\section{CONCLUSION}

Based on the result of this reasearch, phenomenon of code switching is happened in group presenation of class A2 English Education IKIP Siliwangi Bandung. All of the groups presentation, group 1, group 2, and group 3 were doing intra-sentential switching in classroom activity. They were switching their language Indonesia and English. The reasons why students switch their code its is because they have less vocabulary, to make they easier to express or tell their ideas or words, to make the listener more understands about what they said, and because they nervous that make them forget about what they want to say in target language. The situations that they usually switch their code or language are in presentation, group discussion, speech, and conversation daily life.

\section{ACKNOWLEDGEMNT}

During completing the journal the researchers obtained many help suggestion and motivation from many people. For that reason, the researcher would like to express his praise to Allah SWT who has enabled the researchers to finish this journal. Peace and salutation for Muhammad SAW. The researcher also would like to express his gratitude to Dr.H.Heris Hendriana,M.Pd.as 
head of IKIP Siliwangi, Dr.Irma Savitri Sadikin M.Pd.as head of English Education Study Program, Trisnendri Syahrizal S.Pd., M.Hum.and Mr.Yana M.Pd as our supervisors, thanks for carefull guidance to accomplish the journal.

\section{REFERENCES}

Appel., R., \& Muysken, P. (1987). Language contact and bilingualism. London and Baltimore. Edward Arnold.

Aranoff, M., Rees, \& Miller, J. (2003). The Handbook of Linguistics. Blackwll: Oxford.

D, C. (1987). The Cambridge Encyclopedia Of Language. Cambridge: Cambridge University Press.

Hughes, B., Baldwin, T., Bird, S., Nicholson, J., \& MacKinlay, A. (2006). Reconsidering language identification for written language resources. In Proc. of the 5th Edition of the International Conference on Language Resources and Evaluation (LREC 2006). genoa, italy.

Kaswan, \& Suprijadi, D. (2011). A Brief Introduction : Language In Society. Bandung: STKIP Siliwangi Press.

Li, D. C. S. (2008). Understanding mixed code and classroom code-switching: myths and realities. New Horizons in Education, 56(3), 75-87.

Nur, N. A. (2016). a Descriptive Analysis of English Indonesian Code, 82-95.

R Wardhaugh. (2006). An Introduction To Sociolinguistics. Great Britain: Blackwell.

Romaine, S. (1992). bilingualism. Blackwell: Cambridge.

Yuliana, N., Luziana, A. R., \& Sarwendah, P. (2015). Code-Mixing and Code-Switching of Indonesian Celebrities: A Comparative Study. LINGUA CULTURA, 9(1), 47-54. 